International Business and Global Economy 2018, no. 37, pp. 286-298

Biznes międzynarodowy w gospodarce globalnej 2018, nr 37, s. 286-298

Edited by the Institute of International Business, University of Gdańsk

ISSN 2300-6102

e-ISSN 2353-9496

DOI 10.4467/23539496IB.18.020.9393

Jakub M. Kwiatkowski

Uniwersytet Gdański

\title{
Struktura akcjonariatu a polityka wypłacania dywidend spółek prowadzących działalność badawczo-rozwojową w Polsce
}

Poznanie zasad, którymi kierują się przedsiębiorstwa podczas wypłacania dywidend, nurtuje ekonomistów na całym świecie od niemal siedmiu dekad. Z uwagi na różnorodność czynników wpływających na decyzje o wypłacie dywidendy problem określony został mianem "the dividend puzzle". Niniejsze badanie skupia się na dwóch determinantach wypłat dywidendy działalności badawczo-rozwojowej oraz obecności państwa w strukturze akcjonariatu wśród spółek notowanych na Giełdzie Papierów Wartościowych w Warszawie w latach 1992-2016. W badaniu wykorzystano nieparametryczne metody statystyczne w celu weryfikacji zależności pomiędzy tymi czynnikami oraz polityką wypłat dywidendy 296 spółek. Badanie wykazało, iż zarówno działalność badawczo-rozwojowa, jak i obecność państwa w strukturze akcjonariatu wiąże się z przeciętnie niższym poziomem dywidendy wypłacanym przez spółkę. Część pierwsza artykułu prezentuje przegląd literatury z zakresu polityki wypłat dywidend oraz hipotezy badawcze, druga opisuje wykorzystane metody i próbę badawczą, trzecia przedstawia wyniki analizy, a część ostatnia podsumowuje badanie.

Słowa kluczowe: polityka wypłat dywidend, determinanty wypłat dywidend, B+R, państwo w strukturze akcjonariatu

Klasyfikacja JEL: G35

\section{The ownership structure, R\&D activity, and dividend policy of companies listed on the Warsaw Stock Exchange}

For almost seven decades, the rules determining the dividend policy of companies have been the subject of interest of researchers worldwide. Due to the variety of factors influencing managers' decisions on dividend payouts, the issue has been named "the dividend puzzle". The following research focuses on two determinants of dividend policy - research and development activity and government ownership of companies listed on the Warsaw Stock Exchange over the period 1992-2016. We utilize a non-parametric statistical approach to financial data obtained from 296 companies to verify how both factors are related to the dividend policy of companies. We find that both R\&D activity and government ownership have an adverse impact on dividend payouts. The first section of the paper presents the literature review and research hypotheses. The second section presents utilized methods and the data sample. Section three shows the obtained results, and finally, the last section summarizes the research.

Keywords: dividend policy, dividend determinants, R\&D, government ownership

JEL classification: G35 


\section{Wprowadzenie}

Od niemal siedmiu dekad ekonomiści starają się poznać zasady wypłaty dywidend przez przedsiębiorstwa notowane na giełdach papierów wartościowych. Jak zauważają Allen i Michaely [2002], decyzje, w jaki sposób, jak często i jaką częścią zysku należy się podzielić $\mathrm{z}$ akcjonariuszami, istotne są nie tylko z uwagi na samą wartość rozpatrywanych przepływów finansowych od przedsiębiorstwa do akcjonariuszy. Ich znaczenie wynika również ze ścisłego powiązania decyzji o wypłacie dywidendy z większością decyzji finansowych i inwestycyjnych przedsiębiorstw. W literaturze przedmiotu zwraca się uwagę na szereg determinant wypłaty dywidend, od wielkości i zyskowności spółek począwszy, a na strukturze akcjonariatu i podatkach kończąc. W niniejszym opracowaniu skoncentrowano się na dwóch z nich: działalności badawczo-rozwojowej i udziale państwa w strukturze akcjonariatu, a także zależności pomiędzy nimi a polityką wypłacania dywidend spółek notowanych na Giełdzie Papierów Wartościowych w Warszawie.

Pierwsza część opracowania zawiera syntetyczny przegląd dotychczasowych badań w zakresie polityki wypłacania dywidend, w drugiej przedstawiono wybraną metodę analizy oraz próbę badawczą, w trzeciej natomiast zaprezentowano otrzymane wyniki. Opracowanie kończy się podsumowaniem.

\section{Przegląd literatury}

Fakt, że dla przedsiębiorstw dylemat dotyczący wypłaty dywidendy nie jest jednorazowy, lecz ma charakter regularny, jako jeden z pierwszych zauważył Lintner [1956]. Oznacza to, że przedsiębiorstwa, które osiągają dodatni wynik finansowy, muszą zadecydować o wypłacie dywidendy (lub zaniechaniu jej) przynajmniej raz do roku. Regularny charakter decyzji dywidendowych skłonił Lintera do określenia tego procesu mianem „polityki” wypłacania dywidend i pojęcie to do dziś stosuje się powszechnie w literaturze przedmiotu. Ponadto Lintner na podstawie doświadczeń 28 amerykańskich spółek zauważył, że firmy, określając wysokość wypłaty dywidendy, bazują przede wszystkim na wysokości poprzednich wypłat. Wyjaśnił on, że powodem tego zjawiska jest ocena menedżerów spólek, którzy uważają, że inwestorzy mają większe zaufanie do przedsiębiorstw o stabilnej polityce wypłacania dywidend. Zauważył też, że podstawowym czynnikiem wpływającym na zmianę wysokości wypłaty jest zmiana w wysokości zysku firmy. Należy podkreślić, że zdaniem Lintnera wraz ze wzrostem lub spadkiem zysku przedsiębiorstwa dostosowują wysokość dywidendy $\mathrm{w}$ stopniu mniejszym niż proporcjonalny. Innymi słowy, dywidendy charakte- 
ryzuje pewna lepkość, określana w literaturze wygładzaniem dywidend (dividend smoothing $)^{1}$.

Ogromne znaczenie $\mathrm{w}$ zakresie polityki wypłacania dywidend przypisuje się badaniom prowadzonym przez Millera i Modiglianiego [1961], którzy wykazali, że wypłata dywidendy nie decyduje o wartości spółki (dividend irrelevance hypothesis), a jedynie stanowi różnicę pomiędzy zyskiem a inwestycjami. Stanowisko przyjęte przez Millera i Modiglianiego było przeciwne ówcześnie wiodącym przekonaniom wskazującym na istotny wpływ wysokości dywidendy na wartość spółki.

W prowadzonych badaniach poszukiwano wyjaśnień zarówno decyzji o wypłacie dywidendy i różnic w poziomach wypłacanych dywidend, jak i efektów wypłaty dywidendy na wartość spółki. Wskazywane w literaturze determinanty wypłaty dywidendy można podzielić na szereg grup. Przykładowo Kowerski [2011] wyróżnia determinanty fundamentalne, rynkowe, fundamentalno-rynkowe, związane z wiekiem i sektorem spółek oraz dywidendą w roku poprzedzającym. W badaniach empirycznych analizie poddaje się najczęściej determinanty fundamentalne, odnoszące się do zyskowności, rentowności, płynności oraz zadłużenia spółek [zob. Obradovich, Gill, 2013; Javakhadze, Ferris, Sen, 2014]. W innych opracowaniach podejmowany jest problem wpływu polityki podatkowej lub też struktury właścicielskiej na występowanie i wysokość dywidend.

Sam Lintner [1956] poruszył temat wpływu polityki fiskalnej na wypłacanie dywidend. Zauważył, że czym wyższy podatek zapłacić musi przedsiębiorstwo, tym niższy jest jego zysk netto, co implikuje niższą wartość dywidendy dla akcjonariuszy. Problem ten analizują również Miller i Modigliani [1961], którzy omawiają wpływ polityki wypłacania dywidend na różne grupy inwestorów, natomiast Stiglitz [1983] oraz Miller i Scholes [1978] rozważają strategie optymalizacji opodatkowania dywidend.

Oddziaływanie struktury własności spółki na decyzję o wypłacie dywidendy rozpatrywali m.in. Michaely i Roberts [2012]. Wymienieni autorzy na podstawie 8751 brytyjskich spółek wskazują, że spółki z rządowym akcjonariuszem wypłacają wyższe dywidendy, co wynika z większego prawdopodobieństwa wystąpienia problemu agencji. Gugler [2003] twierdzi, iż w przypadku spółek państwowych jest on wręcz podwójny - występuje pomiędzy kadrą zarządczą a nadzorującymi ich politykami, lecz także pomiędzy politykami a „ostatecznymi” właścicielami spółek, czyli społeczeństwem.

W ostatnich latach uwaga badaczy w coraz większym stopniu koncentruje się na głębszych determinantach polityki dywidend. Pośród nich szczególną rolę przypisuje się wydatkom badawczo-rozwojowym lub też szerzej rozumianej innowacyjności, czyli możliwości kreowania nowych rozwiązań w zakresie pro-

\footnotetext{
1 Szerzej na ten temat zob. [Mosionek-Schweda, Mrzygłód, Nowak, 2017].
} 
duktów, procesów, organizacji czy marketingu, których celem jest poprawa pozycji konkurencyjnej przedsiębiorstwa, m.in. poprzez poszerzenie oferty wyrobów, wejście na nowe rynki czy obniżenie kosztów i poprawę organizacji miejsca pracy [OECD, 2008]. Podejście to stara się łączyć politykę wypłaty dywidendy, a więc maksymalizacji wartości dla akcjonariuszy (shareholder value), z możliwością wzrostu i rozwoju spółki, które często postrzegane są jako przeciwstawne cele funkcjonowania przedsiębiorstwa ${ }^{2}$. Jednym z pierwszych autorów, którzy połączyli obie płaszczyzny, był La Porta, który na podstawie próby liczącej 4 tys. spółek pochodzących z 33 krajów wnioskował, że firmy szybko rozwijające się wypłacają niższe dywidendy [La Porta i in., 2000]. Z kolei Fama i French [2001] wykazali, że skłonność do wypłacania dywidendy i jej wysokość są odwrotnie proporcjonalne do możliwości inwestycyjnych i potencjału wzrostu spółki. Potencjał ten zdefiniować można w różny sposób, a jedną z najczęściej stosowanych interpretacji jest utożsamienie go z wydatkami badawczo-rozwojowymi. Takie podejście potwierdzone jest również w pracach Guglera [2003], który analizuje spółki austriackie. Z kolei Shin, Kwon i Kim [2011] dodają, iż wydatki badawczo-rozwojowe pozytywnie wpływają na rentowność spółki i wyższą stopę zwrotu z inwestycji w dłuższym okresie.

Jak zauważa Jeong [2013], determinanty polityki wypłaty dywidendy poddawane są weryfikacji przede wszystkim dla rynków rozwiniętych (najczęściej państw anglosaskich), w znacznie mniejszym stopniu problemy te podejmowane są jednak w analizach empirycznych mniej rozwiniętych rynków kapitałowych. Celem niniejszego opracowania jest weryfikacja zależności pomiędzy wydatkami badawczo-rozwojowymi a polityką wypłacania dywidend spółek notowanych na Giełdzie Papierów Wartościowych w Warszawie. Z perspektywy międzynarodowej polska giełda papierów wartościowych jest rynkiem relatywnie małym. Niniejsze badanie ma unikalny charakter nie tylko ze względu na występowanie luki poznawczej w zakresie wpływu wydatków badawczo-rozwojowych na politykę wypłacania dywidend $\mathrm{w}$ Polsce, lecz także z uwagi na specyfikę rynku rozwijającego się, jakim jest GPW. Zdaniem Jeonga [2013] rynki rozwijające się mogą być determinowane przez inne czynniki, ponadto kierunek oddziaływania determinant może być odmienny niż w przypadku rynków rozwiniętych.

Dodatkowym celem opracowania jest porównanie polityki wypłacania dywidend spółek prowadzących działalność innowacyjną w zależności od struktury ich własności. Podobnie jak w pracy Guglera [2003] skoncentrowano się na udziale Skarbu Państwa w strukturze akcjonariatu, ponieważ można założyć, iż spółki te wypłacają wyższe dywidendy w porównaniu ze spółkami bez akcjonariusza publicznego. Jedno z wyjaśnień tego zjawiska stanowią tzw. koszty agencji (agency costs), czyli rozbieżne cele różnych grup interesariuszy spółek [szerzej na ten temat

2 Szerzej na temat celów przedsiębiorstwa zob. [Horbaczewska, 2012]. 
np. Maury, Pajuste, 2002]. Praca Guglera [2003] nie odpowiada jednak jasno na pytanie o to, jak wyglądać będzie polityka wypłacania dywidend spółek, które prowadzą działalność badawczo-rozwojową, a jednocześnie ich akcjonariuszem jest państwo, a tym samym o to, która z powyższych własności (innowacyjność czy udział Skarbu Państwa) okaże się dominująca. Według wiedzy autora temat ten nie został jeszcze podjęty przez badaczy zajmujących się polską giełdą.

Podsumowując powyższe rozważania, sformułowano następujące hipotezy badawcze:

H1: Przedsiębiorstwa prowadzące działalność badawczo-rozwojową charakteryzują się mniejszą skłonnością do wypłaty dywidendy niż pozostałe spółki notowane na GPW.

H2: Przedsiębiorstwa, których akcjonariuszem jest Skarb Państwa, charakteryzują się wyższą skłonnością do wypłaty dywidendy niż pozostałe spółki notowane na GPW.

H3: Przedsiębiorstwa prowadzące działalność badawczo-rozwojową, których akcjonariuszem jest Skarb Państwa, będą bardziej skłonne do wypłaty dywidendy niż pozostałe spółki zaangażowane w badania i rozwój notowane na GPW.

\section{Materiały i metody}

Do weryfikacji hipotez badawczych wykorzystano dane spólek notowanych na warszawskiej Giełdzie Papierów Wartościowych w latach 2002-2016, uzyskane z serwisu Thomson Reuters Eikon $4^{3}$. W celu uzyskania możliwie szerokiej próby badawczej wstępna lista spółek obejmowała wszystkie 398 przedsiębiorstwa wchodzące w skład Warszawskiego Indeksu Giełdowego (WIG) według stanu na czerwiec 2017 r. ${ }^{4}$ Spośród spółek ze wstępnej listy 296 wypłaciło dywidendę przynajmniej jeden raz w przyjętym okresie analizy. Zgodnie z przedstawioną literaturą decyzja o wypłacie dywidendy ma charakter powtarzalny, co pozwoliło na utworzenie końcowej próby badawczej składającej się z 1599 wypłat dywidend (obserwacji).

W tabeli 1 zawarto podstawowe statystyki opisowe omawianej próby dla podstawowego wskaźnika obrazującego wysokość dywidendy, czyli wielkość dywidendy na 1 akcję (dividend per share - DPS). Dla wszystkich 1599 obserwacji średni poziom DPS wyniósł w okresie badawczym 2,169 PLN i był wyższy od mediany (0,577 PLN), co wskazuje na prawostronną asymetrię rozkładu zmiennej. Wnio-

3 Dane uzyskane w ramach umowy o współpracy pomiędzy Uniwersytetem Gdańskim a firmą Thomson Reuters.

4 Autor niniejszego opracowania jest świadom, że badaniem nie objęto spółek, które dokonały delistingu w okresie analizy, jednakże uzyskanie pełnych informacji finansowych na temat takich spółek nie było możliwe. 
sek ten potwierdza rysunek 1 - dominująca część, tj. 1054 obserwacji, znajduje się w przedziale (0-1 PLN dywidendy na jedną akcję spółki, wobec 545 obserwacji $\mathrm{w}$ pozostałych przedziałach.

Tabela 1. Statystyki opisowe wskaźnika DPS

\begin{tabular}{|l|c|c|c|c|c|c|}
\hline \multicolumn{1}{|c|}{ Zakres próby } & $\begin{array}{c}\text { Liczba } \\
\text { obserwacji }\end{array}$ & Średnia & Mediana & $\begin{array}{c}\text { Odchylenie } \\
\text { standardowe }\end{array}$ & Min. & Max. \\
\hline Wszystkie spółki & 1599 & 2,169 & 0,577 & 7,842 & 0,001 & 190 \\
\hline $\begin{array}{l}\text { Spółki zaangażowane } \\
\text { w B+R }\end{array}$ & 160 & 0,726 & 0,400 & 0,927 & 0,081 & 8,24 \\
\hline $\begin{array}{l}\text { Spółki niezaangażowane } \\
\text { w B+R }\end{array}$ & 1439 & 2,329 & 0,610 & 8,245 & 0,001 & 190 \\
\hline
\end{tabular}

Źródło: Opracowanie własne w programie Stata 14.

W trzecim i czwartym wierszu tabeli 1 przedstawiono wyniki statystyk opisowych w podziale na spółki prowadzące działalność badawczo-rozwojową $(B+R)$ i nieprowadzące jej. Zarówno średnia, jak i mediana obserwacji spółek prowadzących działalność badawczo-rozwojową jest niższa niż w wypadku spółek niezaangażowanych w B+R. Wyniosły one odpowiednio 0,726 i 0,4 w przypadku spółek zaangażowanych w B+R oraz 2,329 i 0,61 dla pozostałych. Odchylenie standardowe wyniosło w przypadku spółek prowadzących działalność badawczorozwojową 0,927 i było znacznie niższe od odchylenia standardowego pozostałych spółek - 8,245. Obie wartości skrajne próby - maksymalna (190) i minimalna $(0,001)$ - dotyczyły spółek niezaangażowanych w B+R.

Identyfikacja przedsiębiorstw zaangażowanych w działalność badawczo-rozwojową na polskim rynku giełdowym jest relatywnie trudna w porównaniu z wieloma rynkami zagranicznymi. Wynika to z faktu, że w odróżnieniu od spółek notowanych na giełdach azjatyckich, zachodnioeuropejskich czy amerykańskich, spółki notowane na GPW nie ujawniają w odrębnej pozycji bilansu rocznego wydatków na działalność $B+R$. W związku z tym w celu określenia, czy spółki inwestują w badania i rozwój, wykorzystano pozycję bilansu rocznego określającą wartości niematerialne, która uwzględnia 5 :

- skapitalizowane wydatki na rozwój oprogramowania;

- przedpłaty na licencje;

- koszty franchisingu;

- skapitalizowane koszty działalności badawczo-rozwojowej;

- koszty zdjęć, filmów, bibliotek DVD w spółkach filmowych/rozrywkowych;

- prawa do transmisji, koncesje nadawcze, franczyzy kablowe;

5 Zakres pozycji określającej wartości niematerialne jest zgodny z zapisem dostępnym w produkcie Eikon 4 firmy Thomson Reuters dla spólek polskich. 
- koszty nabycia list potencjalnych klientów;

- prawa do obsługi hipotek nabyte w bankach i innych instytucjach finansowych;

- prawa dostępu oraz wykorzystanie wody w spółkach wodociągowych.

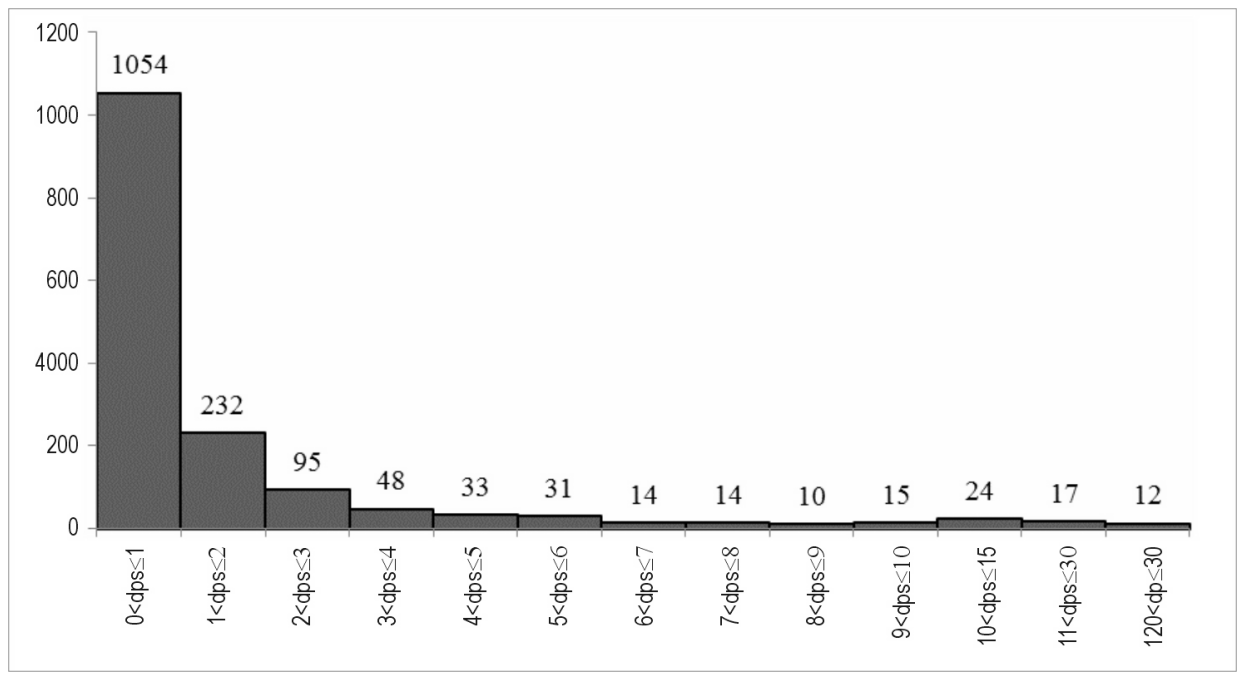

Rysunek 1. Rozkład wskaźnika DPS

Źródło: Opracowanie własne w programie Statistica 13.

Większość powyższych składowych jest zgodna ze wskaźnikami stosowanymi w literaturze dotyczącej działalności innowacyjnej, należy jednak pamiętać, że sumaryczne ich ujęcie w ramach jednej pozycji bilansu - wartości niematerialne uniemożliwia jednoznaczne określenie, czy wybrana spółka prowadzi działalność badawczo-rozwojową. Ponadto porównywanie wielkości absolutnych pozycji wartości niematerialnych, a nie relatywnych pomiędzy spółkami, może prowadzić do błędnych wniosków. Z tych dwóch powodów zdecydowano się na obliczenie i zastosowanie relatywnej miary działalności innowacyjnej, która przyjęła następującą postać:

$$
\text { inn }_{i}=\frac{\text { wartość aktywów niematerialnych (PLN) }}{\text { wartość aktywów ogółem (PLN) }}
$$

gdzie:

i - spółka.

Z uwagi na silnie lewostronną asymetrię rozkładu wskaźnika (rys. 2) za spółki zaangażowane $\mathrm{w}$ działalność $\mathrm{B}+\mathrm{R}$ uznano te, które znajdują się $\mathrm{w} 10$ ostatnich percentylach rozkładu wskaźnika. Są to zatem spółki, dla których wskaźnik wy- 
nosi co najmniej 0,088. Pozostałe podmioty uznano za spółki, w których działalność badawczo-rozwojowa nie odgrywa kluczowej roli.

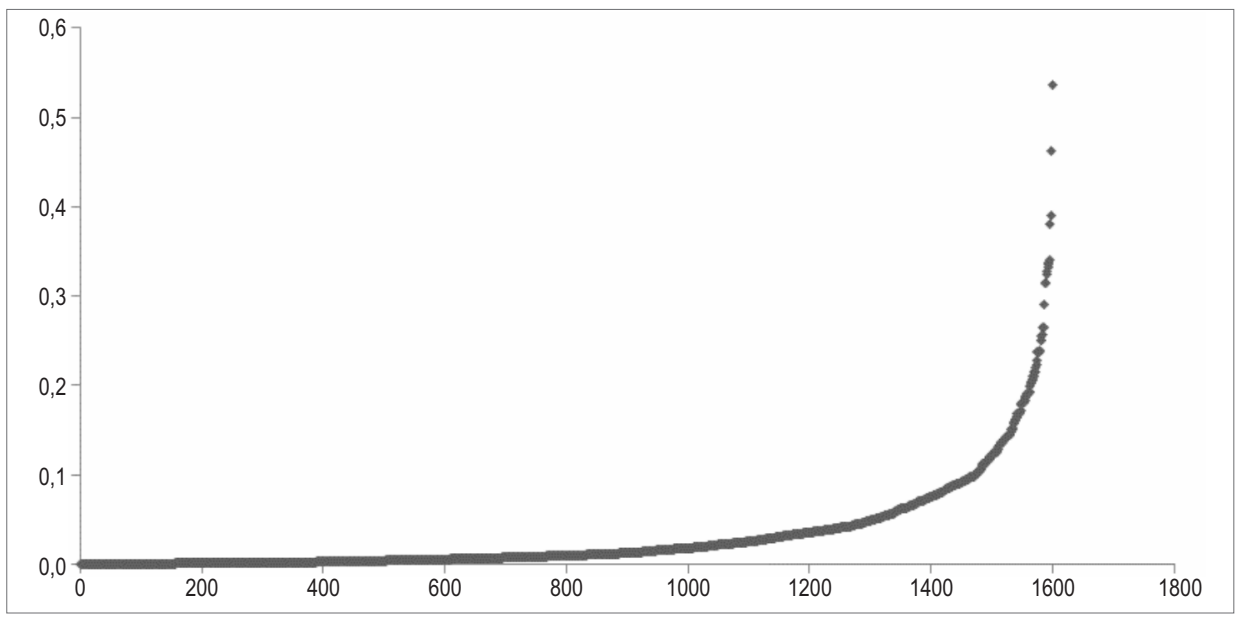

Rysunek 2. Rozkład miary działalności innowacyjnej

Źródło: Opracowanie własne w programie Statistica 13.

Należy zaznaczyć, iż z uwagi na coroczne zmiany wartości aktywów (w tym niematerialnych) spółek współczynnik zaangażowania $\mathrm{w} B+\mathrm{R}$ również ulegał zmianom. Tym samym każda spółka, w zależności od roku wypłaty dywidendy, mogła zostać zakwalifikowana jako zaangażowana w badania i rozwój w jednym roku, a także jako niezaangażowana w kolejnym.

Przedstawiony w tym punkcie proces doboru próby badawczej został przedstawiony na rysunku 3.

Tabela 2 przedstawia statystyki opisowe zmiennej zarówno dla wszystkich spółek, jak i w podziale na zaangażowane oraz niezaangażowane w działalność badawczo-rozwojową. We wszystkich grupach średnia jest wyższa od mediany wynoszą odpowiednio 0,031 i 0,009 w przypadku całej próby, 0,163 i 0,138 dla spółek zaangażowanych w B+R, a dla niezaangażowanych 0,016 i 0,007, co potwierdza silnie asymetryczny rozkład zmiennej.

Zależność pomiędzy obiema zmiennymi - wysokością dywidendy oraz zaangażowaniem w działalność badawczo-rozwojową - zaprezentowano na rysunku 4. Wykres ukazuje nieliniową relację pomiędzy wskaźnikami. Spółki z wysokim wskaźnikiem działalności innowacyjnej położone są wzdłuż osi rzędnych, a pozostałe wzdłuż osi odciętych, co potwierdza zasadność dalszej analizy. 


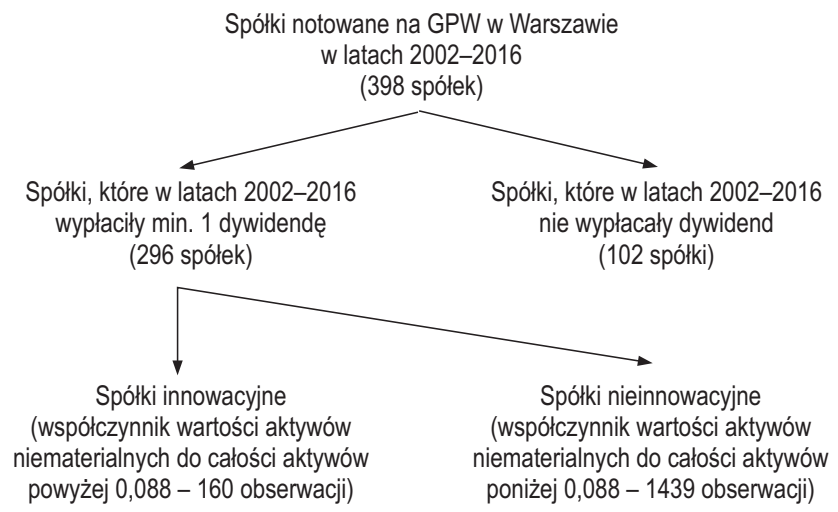

Rysunek 3. Schemat doboru próby badawczej

Źródło: Opracowanie własne.

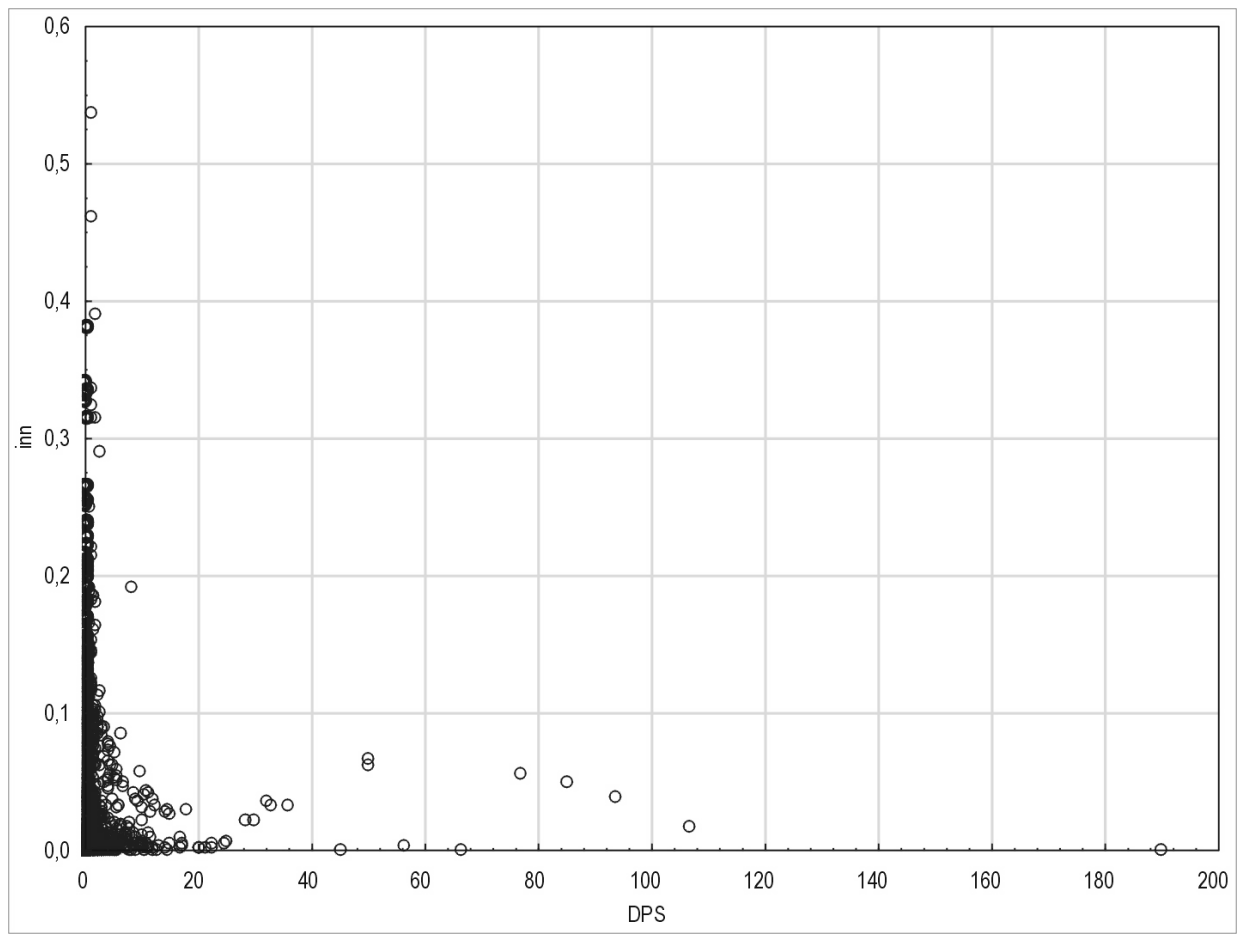

Rysunek 4. Zależność między zaangażowaniem w B+R a wysokością dywidend Źródło: Opracowanie własne w programie Statistica 13. 
Tabela 2. Statystyki opisowe wskaźnika działalności innowacyjnej

\begin{tabular}{|l|c|c|c|c|c|c|}
\hline \multicolumn{1}{|c|}{ Zakres próby } & $\begin{array}{c}\text { Liczba } \\
\text { wypłat }\end{array}$ & Średnia & Mediana & $\begin{array}{c}\text { Odchylenie } \\
\text { standardowe }\end{array}$ & Min. & Max. \\
\hline Wszystkie obserwacje & 1599 & 0,031 & 0,009 & 0,540 & 0 & 0,537 \\
\hline $\begin{array}{l}\text { Spółki zaangażowane } \\
\text { w B+R }\end{array}$ & 160 & 0,163 & 0,138 & 0,780 & 0,089 & 0,537 \\
\hline $\begin{array}{l}\text { Spółki niezaangażowane } \\
\text { w B+R }\end{array}$ & 1439 & 0,016 & 0,007 & 0,021 & 0 & 0,088 \\
\hline
\end{tabular}

Źródło: Obliczenia własne w programie Stata 14.

Z uwagi na wskazaną asymetrię rozkładu w celu weryfikacji pierwszej hipotezy badawczej wykorzystano nieparametryczny test U Manna-Whitneya, którego hipoteza zerowa mówi, że rozkłady dwóch populacji są identyczne. Zgodnie z przedstawionym przeglądem literatury spółki zaangażowane w działalność badawczo-rozwojową wypłacają przeciętnie niższe dywidendy niż pozostałe podmioty.

Następnie, aby zweryfikować drugą hipotezę badawczą, z próby badawczej wydzielono spółki, których akcjonariuszem, niezależnie od wielkości udziału, jest Skarb Państwa, tj. PGNiG, PGE, PZU, PKO BP, PKN Orlen, KGHM, Energa, Enea, Lotos, Tauron Polska Energia, Grupa Azoty, PKP Cargo, Jastrzębska Spółka Węglowa, Polski Holding Nieruchomości, Giełda Papierów Wartościowych, Zakłady Chemiczne Police oraz Elektrociepłownia Będzin. Spółki te wypłacają dywidendę relatywnie regularnie, co dało w przypadku wybranego okresu badania łącznie 118 obserwacji. Ponownie do oceny identyczności rozkładów spółek z udziałem akcjonariusza publicznego oraz bez jego udziału wykorzystano nieparametryczny test U Manna-Whitneya. Zgodnie z teorią asymetrii informacji spółki z udziałem Skarbu Państwa powinny wypłacać wyższe i bardziej regularne dywidendy, aby przekonać wyborców o dobrej kondycji finansowej spółek oraz zapobiec wystąpieniu problemu agencji.

Aby zweryfikować ostatnią hipotezę, z grupy spółek zaangażowanych w działalność badawczo-rozwojową wydzielono obserwacje spółek, których akcjonariuszem jest Skarb Państwa, a następnie przeprowadzono nieparametryczny test U Manna-Whitneya, w którym porównywanymi grupami były: spółki z udziałem Skarbu Państwa oraz pozostałe spółki prowadzące działalność innowacyjną. Liczba obserwacji wyniosła odpowiednio 4 oraz 156.

\section{Wyniki analizy}

Na podstawie testu U Manna-Whitneya przy założonym poziomie istotności 0,05 można stwierdzić, że rozkłady obydwu grup spółek różnią się istotnie przy $\mathrm{p}=0,000$. Średnia suma rang jest wyższa dla spółek, które nie są zaangażowane 
w działalność $B+R$. Zatem wyniki potwierdzają hipotezę o przeciętnie wyższej wypłacie dywidend przez spółki, które nie były zaangażowane w działalność badawczo-rozwojową od spółek zaangażowanych $w$ działalność $B+R$. Wynik testu statystycznego zaprezentowano $\mathrm{w}$ tabeli 3 .

Tabela 3. Wynik testu U Manna-Whitneya dla spółek zaangażowanych w działalność $\mathrm{B}+\mathrm{R}$ dla wskaźnika DPS

\begin{tabular}{|c|c|c|c|c|c|c|c|c|}
\hline $\begin{array}{c}\text { Suma rang } \\
- \text { pozostałe } \\
\text { spółki }\end{array}$ & $\begin{array}{c}\text { Suma rang } \\
\text { - spółki za- } \\
\text { anga- } \\
\text { żowane } \\
\text { w B+R }\end{array}$ & $\mathrm{U}$ & $\mathrm{Z}$ & $\mathrm{p}$ & $\mathrm{Z}$ & $\mathrm{p}$ & $\begin{array}{c}\text { N-waż- } \\
\text { nych - } \\
\text { pozozastałe }\end{array}$ & $\begin{array}{c}\text { N-waż- } \\
\text { nych - } \\
\text { zaanga- } \\
\text { żowane } \\
\text { w B+R }\end{array}$ \\
\hline 11373474 & 105726 & 92846 & 4,020 & 0,000 & 4,020 & 0,000 & 1439 & 160 \\
\hline
\end{tabular}

Źródło: Obliczenia własne w programie Statistica 13.

W przypadku spółek z udziałem państwa test U Manna-Whitneya nie potwierdził hipotezy mówiącej o wyższych wypłatach dywidend w spółkach z udziałem Skarbu Państwa w strukturze akcjonariatu. Wręcz odwrotnie - przy założonym poziomie istotności 0,05 i $\mathrm{p}=0,004$ wykazał odwrotną zależność - suma rang w grupie spółek bez udziału państwa okazała się istotnie wyższa. Wynik statystyki zaprezentowany został $\mathrm{w}$ tabeli 4 .

Tabela 4. Wynik testu U Manna-Whitneya dla spółek z udziałem państwa dla wskaźnika DPS

\begin{tabular}{|c|c|c|c|c|c|c|c|c|}
\hline $\begin{array}{c}\text { Suma rang } \\
- \text { z udzia- } \\
\text { łem } \\
\text { państwa }\end{array}$ & $\begin{array}{c}\text { Suma rang } \\
- \text { pozostałe } \\
\text { spółki }\end{array}$ & $\mathrm{U}$ & $\mathrm{Z}$ & $\mathrm{p}$ & $\mathrm{Z}$ & $\mathrm{p}$ & $\begin{array}{c}\text { N-waż- } \\
\text { nych - } \\
\mathrm{z} \text { udzia- } \\
\text { łem } \\
\text { państwa }\end{array}$ & $\begin{array}{c}\text { N-waż- } \\
\text { nych - } \\
\text { pozostałe }\end{array}$ \\
\hline 108349 & 1170851 & 73430 & $-2,890$ & 0,004 & $-2,890$ & 0,004 & 118 & 1481 \\
\hline
\end{tabular}

Źródło: Obliczenia własne w programie Statistica 13.

$\mathrm{Z}$ uwagi na rezultaty powyższych analiz, a także biorąc pod uwagę niewielki zbiór obserwacji spółek zaangażowanych w $\mathrm{B}+\mathrm{R}$ z udziałem państwa w strukturze akcjonariatu (zaledwie 4 obserwacje), weryfikacja ostatniej hipotezy, mówiącej o dominacji jednej z własności spółek - udziału państwa bądź działalności badawczo-rozwojowej, które $\mathrm{w}$ teorii przeciwnie wpływają na politykę dywidend spółek, okazała się niemożliwa. 


\section{Podsumowanie}

Celem niniejszego badania była weryfikacja zależności między intensywnością działalności badawczo-rozwojowej spółek notowanych na warszawskiej Giełdzie Papierów Wartościowych w latach 2002-2016 a polityką wypłat dywidendy.

Jak zauważył Gugler [2003], zgodnie z teorią doskonałego rynku kapitałowego wydatki inwestycyjne przedsiębiorstw, w tym na badania i rozwój, nie powinny wpływać na wysokość wypłacanej dywidendy. Otrzymany wynik badania potwierdza jednak odwrotną zależność między działalnością badawczo-rozwojową a wysokością dywidend. Wynik ten jest sprzeczny z koncepcją doskonałego rynku kapitałowego, aczkolwiek spójny z wnioskami zaprezentowanymi w literaturze przedmiotu [np. Shin, Kwon, Kim, 2011].

Badanie nie potwierdziło hipotezy dotyczącej dodatniej zależności pomiędzy udziałem państwa w strukturze akcjonariatu a wysokością wypłacanych dywidend - wręcz odwrotnie, relacja $\mathrm{w}$ analizowanym okresie okazała się ujemna. Wynik ten tłumaczyć można wzorem Jeonga [2013], który dowodzi, iż rynkami rozwijającymi się kierują inne zasady niż rynkami rozwiniętymi. Innym powodem może być niedoskonałość wskaźnika wydatków badawczo-rozwojowych spółek.

Bez wątpienia badany temat wymaga dalszej analizy, zarówno pod kątem wpływu działalności $B+R$, jak i udziału państwa w strukturze akcjonariatu. Pociąga to jednak za sobą konieczność wykorzystania dokładniejszych miar (wysokości wydatków badawczo-rozwojowych sensu stricto, wysokości udziału państwa w spółkach) oraz dłuższego okresu, które nie są obecnie dostępne. Do ciekawych wniosków mogłaby prowadzić również analiza sektorowa badanych zjawisk.

\section{Bibliografia}

Allen F., Michaely R., 2003, Payout Policy, [w:] Handbook of Economics, eds. G. Constantinides, M. Harris, R. Stulz, North-Holland, Amsterdam.

Fama E.F., French K.R., 2001, Disappearing dividends. Changing firm characteristics or lower propensity to pay?, Journal of Financial Economics, vol. 60, no. 1.

Gugler K., 2003, Corporate governance, dividend payout policy, and the interrelation between dividends, RED, and capital investment, Journal of Banking \& Finance, no. 27.

Horbaczewska B., 2012, Wyptaty dla akcjonariuszy a wycena akcji na rynku kapitałowym, CeDeWu, Warszawa.

Javakhadze D., Ferris S.P., Sen N., 2014, An international analysis of dividend smoothing, Journal of Corporate Finance, no. 29.

Jeong J., 2013, Determinants of dividend smoothing in emerging market. The case of Korea, Emerging Market Review, no. 17. 
Kowerski M., 2011, Ekonomiczne uwarunkowania decyzji o wypłatach dywidend przez spótki publiczne, Wydawnictwo Konsorcjum Akademickie, Zamość - Kraków - Rzeszów.

La Porta R., Lopez-De Silanes F., Shleifer A., Vishny R., 2000, Agency problems and dividend policy around the world, Journal of Finance, no. 55.

Lintner J., 1956, Distribution of Incomes of Corporations Among Dividends, Retained Earnings, and Taxes, American Economic Review, vol. 46, no. 2.

Maury B., Pajuste A., 2002, Controlling Shareholders, Agency Problems and Dividend Policy in Finland, Finnish Journal of Business Economics, no. 51.

Michaely R., Roberts M.R., 2012, Dividend policies. Lessons from Private Firms, The Review of Financial Studies, vol. 25, no. 3.

Miller M., Modigliani F., 1961, Dividend Policy, Growth and the Valuation of Shares, Journal of Business, no. 34 .

Miller M., Scholes M., 1978, Dividends and Taxes, Journal of Financial Economics, no. 6.

Mosionek-Schweda M., Mrzygłód U., Nowak S., 2017, Do managers really care about shareholders' expectations? Evidence on dividend smoothing on Latin American Emerging Stock Markets, Econometrics/Ekonometria, vol. 2, issue 56.

Obradovich J., Gill A., 2013, Corporate Governance, Institutional Ownership, and the Decision to Pay the Amount of Dividends. Evidence from USA, Faculty Publications and Presentations, Liberty University, no. 26.

OECD, 2008, Podręcznik Oslo. Zasady gromadzenia i interpretacji danych dotyczacych innowacji, wyd. 3, OECD, Warszawa.

Shin M.S., Kwon J.S., Kim S.E., 2011, RED expenditure and dividend smoothing. Evidence from Korean small and medium-sized enterprises, Journal of Finance and Accountancy, vol. 5, no. 1.

Stiglitz J.E., 1983, Some Aspects of the Taxation of Capital Gains, Journal of Public Economics, no. 21.

J.M. Kwiatkowski (-) j.kwiatkowski@ug.edu.pl

Katedra Ekonomiki Integracji Europejskiej, Wydział Ekonomiczny, Uniwersytet Gdański, ul. Armii Krajowej 119/121, 81-824 Sopot, Polska 